\title{
PHYTOTOXIC ACTIVITY OF BIOACTIVE COMPOUNDS FROM FOUR PLANTS AGAINST SELECTED WEEDS IN AGRICULTURE
}

\author{
Tauseef Anwar ${ }^{1}$, Huma Qureshi ${ }^{2 凶}$ \\ ${ }^{1}$ Department of Botany, The Islamia University of Bahawalpur (Bgahdad-ul-Jadeed Campus), Bahawalpur-63100, \\ Pakistan \\ ${ }^{2}$ Institute of Biological Sciences, Gomal University, Dera Ismail Khan-29050, Pakistan
}

\begin{abstract}
\section{Aim of the Study}

Heavy doses of synthetic weed control chemicals have caused herbicide resistance in weeds. Natural compounds produced by living organisms constitute a wide field for ecologically safe herbicides. The The experiments were designed to test allelopathic potential of hexane extracts of selected plants against common weeds in agriculture viz. Euphorbia helioscopia, Rumex dentatus, Phalaris minor, Avena fatua and Chenopodium album.
\end{abstract}

\begin{abstract}
Materials and methods
Allelopathic potential of Carica papaya, Rhazya stricta, Lantana camara and Pinus roxburghii hexane extracts against weeds was determined at $100 \%, 75 \%$ and $50 \%$ concentration on soil, filter paper and agar. Parameters adopted for assessing allelopathic potential were the germination (\%) and the length of seedling (cm). Data analysis was performed using the Statistica 9 software.
\end{abstract}

\section{Results and Conclusion}

The results indicated that $R$. stricta, C. papaya, L. camara and P. roxburghii hexane extracts possesses suppression effects against weeds among which $L$. camara had the most conspicuous inhibition effects on selected weeds. The inhibitory effects of germination and seedling growth were in order $R$. stricta $>$ L. camara $>C$. papaya $>$ P. roxburghii. Field analysis to assess the phytotoxic ability of these species to be used as herbicide is recommended.

Keywords: Bioherbicide, growth supression, phytotoxicity

\section{Introduction}

Synthetic chemicals are widely used for weed control. These chemicals increase crop production, but at the same time they may have a detrimental effect on both the human health and the environment. Additionally, the growth of weeds resistant to man-made weedicides is a major concern. Over the last few years, intensive use of herbicides to suppress weeds is becoming one of the world's prominent ecological and environmen- tal challenges. Residues of herbicides in seeds, underground water and soil that produce health threats and resistant biotypes are dangers that we face,while trying to develop different weed management techniques. Since synthetic chemicals pose negative impact, demand for new classes of chemicals may grow, particularly biodegradable ones, such as plants that may grow as natural herbicides (Aryakia et al., 2015). 
Allelopathy is a natural technique which is environmentally friendly. This is one of potential approaches to weed management that may enhance crop productivity (Kamran et al., 2017). According to Kong and $\mathrm{Hu}$ (2001) "Allelopathy is a science that studies any process involving secondary metabolites developed by plants, micro-organisms, viruses and fungi influencing the growth and development of agricultural and biological systems". Plant-based herbicides will reduce the usage of synthetic weed control herbicides; they will produce less contamination and mitigate concerns related to human health. Alkaloids, benzoic and cinnamic acids, glucosionates, flavonoids, phenolics and terpenes are the most widely available allelochemicals (Khan et al., 2014).

\section{MATERIALS AND METHODS}

The allelopathic potential of leaves of selected plants was evaluated: viz., $R$. stricta, $P$. roxburgii, C. papaya and L. camara. Fresh leaves were collected (at $33^{\circ} 36^{\prime} \mathrm{N}$ latitude, $73^{\circ} 02^{\prime} \mathrm{E}$ longitude) for each species. The plant material was dried in laboratory at $30^{\circ} \mathrm{C}$ and crushed to fine powder using a heavy duty blender (Ramsumair et al., 2014). The samples were kept in airtight zip lock bags (Anwar et al., 2016). Test species seeds viz. Euphorbia helioscopia, Chenopodium album, Avena fatua, Rumex dentatus and Phalaris minor were collected from the Barani Agricultural Research Institute (BARI), Pakistan.

Dry leaf powder (10 gm) of each test species was soaked in $n$-hexane $(100 \mathrm{ml})$ at $25^{\circ} \mathrm{C}$ for 24 hours, which yielded 10 per cent hexane extract stock solution. Dilutions were further prepared i.e. T1 (100 percent), T2 (75 percent), T3 (50 percent). Bioassays have been performed using filter paper and soil as the medium. Extract $(15 \mathrm{ml})$ was poured to $25 \mathrm{~g}$ soil in each petri dish for each of the three concentrations, while $5 \mathrm{ml}$ extract was poured to filter paper. Aluminum foil wrapped petri dishes were kept at $28^{\circ} \mathrm{C}$ for 15 days in growth chamber (NTS Model MI-25S). The percentage of germination (per cent), radicle size, and length of seedling $(\mathrm{cm})$ was calculated by comparison with control (Anwar et al., 2017; Maharjan et al., 2007). The results were statistically analysed using STATISTIX 9 software (Nekonam et al., 2014).

\section{RESULTS AND DISCUSSION}

\section{Phytotoxic activity of R. stricta}

There was a substantial reduction in C. album germination (35 percent), $R$. dentatus (33 percent) and $P$. minor (32 percent), though there was no considerable impact on T. aestivum, E. helioscopia and A. fatua germination presenting opposition to the extract. For $C$. album the highest inhibition of seed germination was noted (47 percent), followed by P. minor (44 percent) and $R$. dentatus (43 percent) applied into the soil. Based on statistical data it was concluded that $R$. dentatus (44 percent) and A. fatua (40 percent) in $R$. strictaa $n$-hexane extract on filter paper exhibited the highest radicle size inhibition activity. Likewise, hexane extract on soil initiated a substantial lessening in the size of $R$. dentatus (51 percent) and A. fatua (50 percent). However, the data indicated that radicle size of C. album, T. aestivum, E. helioscopia and $P$. minor remained unchanged. The minimum radicle size on filter paper and soil was noticed for $R$. dentatus i.e. 56 percent and 49 percent respectively. For C. album, T. aestivum, E. helioscopia and $P$. minor the maximum radicle size ( 96 per cent) was recorded. The current study's experimental findings showed that $n$-hexance extract of $R$. stricta substantially repressed the seedling length of T. aestivum (51\%), A. fatua $(29 \%)$ and $R$. dentatus $(27 \%)$ as opposed to filter paper controls. The seedling elongation of $P$. minor, $C$. album and E. helioscopia was not significantly affected. $R$. stricta hexane extract also substantially checked the seedling lendth of T. aestivum (59\%), R. dentatus (35\%) and A. fatua (56\%) in soil. Arithmetical data suggested that for T. aestivum the minimum size of the seedling was 49 per cent and 42 per cent on soil and on filter paper, respectively. It was indicated that for P. minor, $E$. helioscopia and C. album the average seedling length (95 per cent) was recorded (see: Fig 1).

Such findings are consistent with the results of Alam (1990), where inhibition of the length of the seedling was noted by enhancing application of the R. stricta extract. Zackrisson and Nilsson (1992) observed substantial supression in germination and seedling length of $Z$. mays by $R$. stricta extract. The present findings confirmed the previous findings of Bora et al. (1999) who obseved the inhibitory ability of $R$. strictaa leaves extract on seed growth, seedling length of some agrarian crops. 


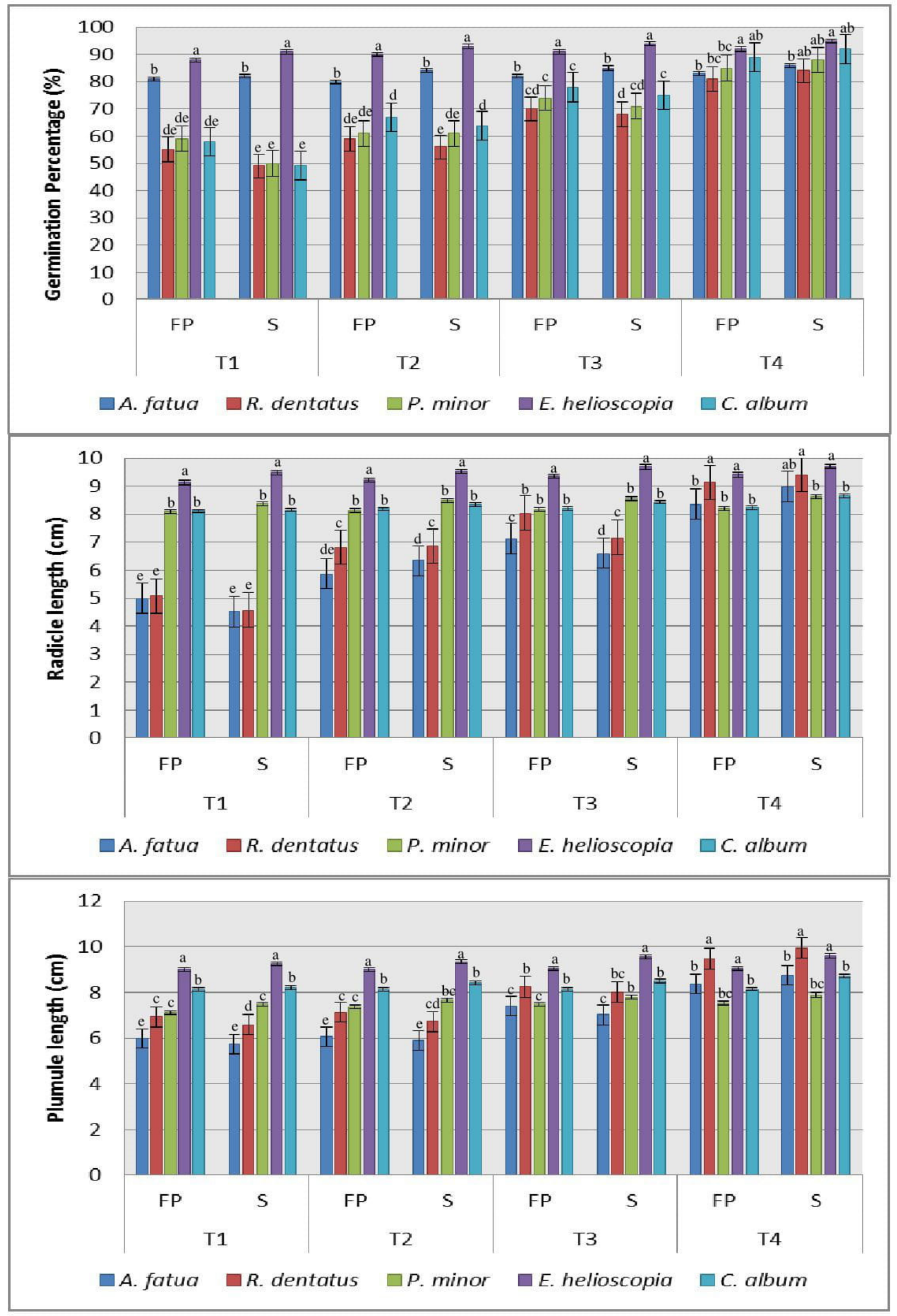

Fig. 1. Phytotoxic activity of $R$. stricta hexane extract against selected weeds (FP=Filter Paper, $\mathrm{S}=$ Soil, $\mathrm{T}=$ Treatment) 


\section{Phytotoxic activity of L. camara}

There was a substantial inhibition in the germination of E. helioscopia (36 percent) followed by $P$. minor (34 percent) and A. fatua (33 percent) compared to filter paper control, while there was no noteworthy impact on the germination of C. album, T. aestivum and $R$. dentatus showing inhibition to $L$. camara extract. Maximum inhibition of seed germination was observed for P. minor (41\%), followed by A. fatua (40\%) and E. helioscopia (39\%) after the introduction of $L$. camara extract into the soil. For $R$. dentatus, T. aestivum and C. album, the maximum germination (97 per cent) was recorded. Minimum germination on filter paper and soil has been noted in the present study for E. helioscopia (66 percent) and P. minor (61 percent), respectively. A concentration-dependent allelopathic effect was observed. A. fatua (39 percent) and $R$. dentatus (35 percent) in L. camara extract exhibited the highest radicle size inhibition activity. Extract on soil induced substantial decrease in the radicle size of A. fatua (40\%) and $R$. dentatus (30\%). The radicle size of E. helioscopia, T. aestivum, C. album and P. minor remained unaffected. Minimum radicle size on filter paper and soil was observed for A. fatua, i.e. 62 per cent and 60 per cent respectively. For T. aestivum, E. helioscopia, C. album and P. minor the maximum radicle size ( 96 per cent) was noted. Data showed that $L$. camara extract considerably repressed $R$. dentatus (46 per cent) and A. fatua (42 per cent) seedling length compared to the filter paper sample. Interestingly, T. aestivum, C. album, P. minor, E. helioscopia and did not have any major effect on seedling elongation. Similarly, $L$. camara extract substantially repressed $R$. dentatus (49 per cent) and A. fatua (45 per cent) seedling length in soil. For T. aestivum, C. album, $P$. minor and E. helioscopia the maximum seedling length (95 per cent) was recorded (see: Fig. 2).

Statistics also suggested that C. album, T. aestivum and $R$. dentatus led to the highest observed values of germination. Limited germination on filter paper and soil was recorded for E. helioscopia and $P$. minor. It was observed that for the E. helioscopia, P. minor, T. aestivum and $C$. album radicle size was the highest. A. fat$u a$ was noted for the lowest radicle size. The data shown that in terms of seedling elongation T. aestivum, C. album, E. helioscopiaand P. minor presented the higest activity. $R$. dentatus was observed to have produced the lowest seedling size. Tadele (2014) noted that extract from $L$. camara leaves suppressed the Eragrostis teff germination significantly. Padhy et al. (2000) stated that seed germination reduction could be due to metabolite imbalances by the allelochemicals in the extract of $L$. camara. All growth factors of Vigna radiata seeds were inhibited by different concentrations of $L$. camara. All parts of the $L$. camara extracts have significantly controlled the growth of Setaria italica, Pennisetum americanum and Lactuca sativa (Hussain et al., 2011).

\section{Phytotoxic activity of C. papaya}

There was a substantial reduction in E. helioscopia germination ( 35 percent) followed by P. minor (33 percent) and $A$. fatua (32 percent), however there was no substantial impact on the germination of C. album, $T$. aestivum and $R$. dentatus as a result of exposure to $C$. papaya extract. The highest inhibition of seed germination was observed for E. helioscopia (50 percent) followed by $P$. minor (46 percent) and $A$. fatua (42 percent), when introducing $C$. papaya extract into the soil. For C. album, R. dentatus and T. aestivum the maximum germination ( 97 per cent) was recorded. The data showed that $T$. aestivum (51 per cent), P. minor (37 per cent) and $R$. dentatus (35.5 per cent) in $C$. papaya extract exhibited the highest radicle size inhibition activity. Hexane extract on soil caused major T. aestivum (57.5 percent), $R$. dentatus (50.5 percent), and $P$. minor (49.5 percent) reduction. The current study's statistical results showed that the radicle size of E. helioscopia, A. fatua and C. album remained unchanged, that is, no impact of the treatment was noted. The findings also tell us that the lowest radicle size was observed on filter paper and soil, for T. aestivum, i.e. 50 percent and 43 percent, respectively. For E. helioscopia, A. fatua and C. album the radicle size ( 96 percent) has been recorded. Data indicated that $C$. papaya extract repressed $P$. minor (35\%) and C. album (34\%) seedling length. Data showed that the seedling elongation of E. helioscopia, T. aestivum, A. fatua and $R$. dentatus had no noteworthy impact. C. papaya extract repressed C. album (49.5 percent) and $P$. minor (48.5 percent) seedling length in soil. The smallest size of the seedling was noted on filter paper and soil for P. minor (66.5 percent) and C. album (51.5 percent). For E. helioscopia, T. aestivum, A. fatua and $R$. dentatus the maximum seedling length ( 95 per cent) was noted (see: Fig. 3). 


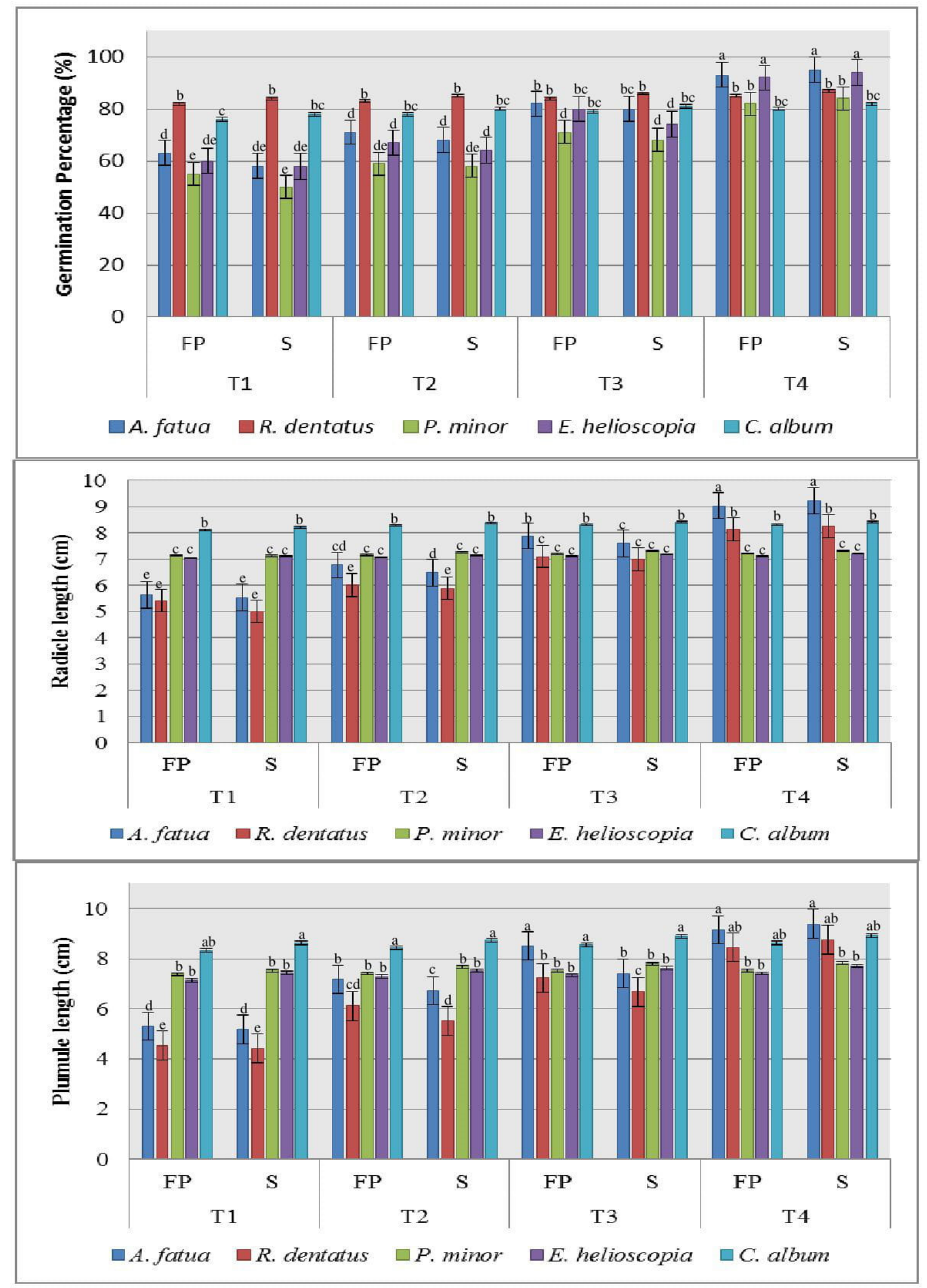

Fig. 2. Phytotoxic activity of $L$. camara hexane extract against selected weeds (FP=Filter Paper, $\mathrm{S}=$ Soil, $\mathrm{T}=$ Treatment) 


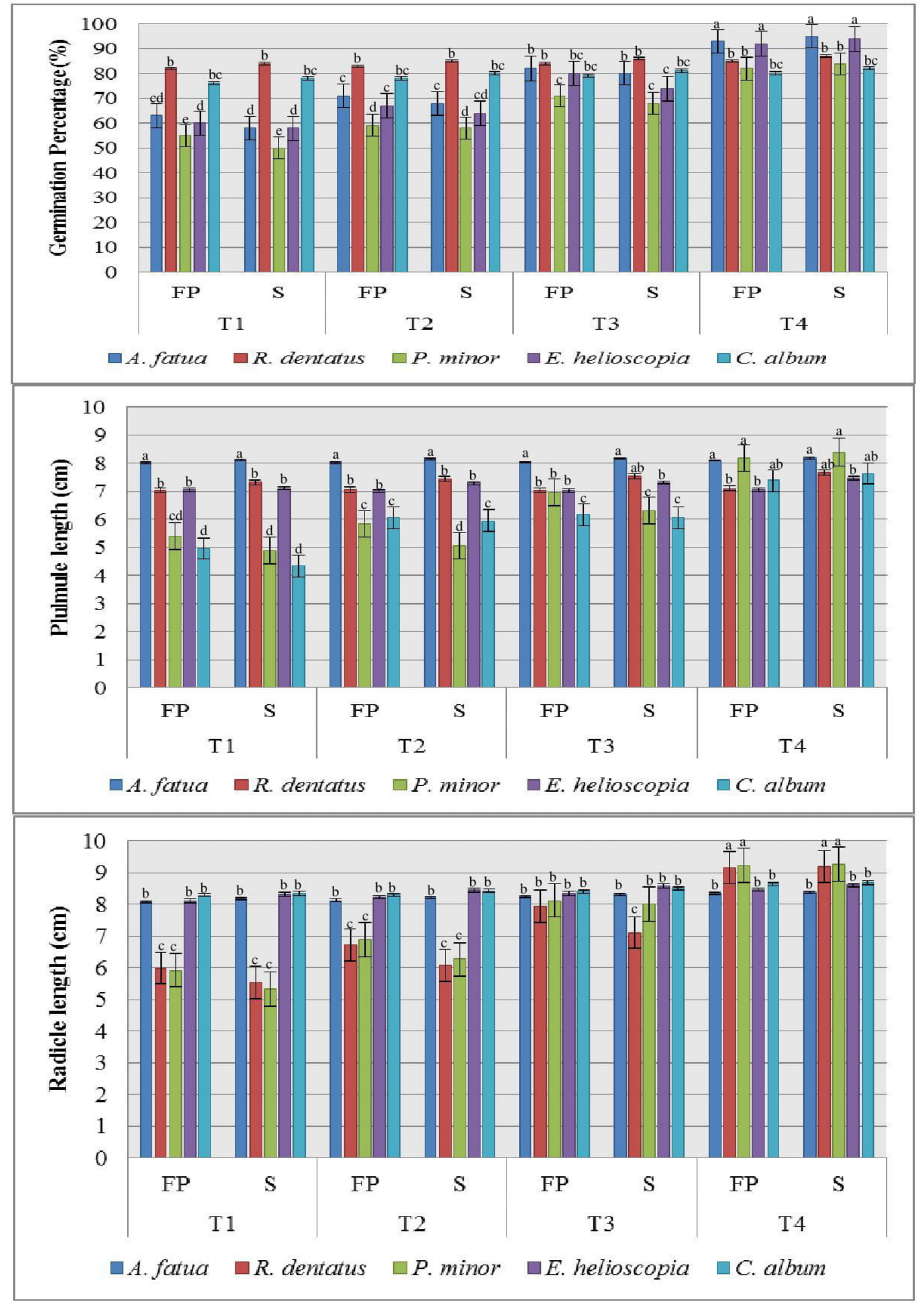

Fig. 3. Phytotoxic activity of $C$. papaya hexane extract against selected weeds $(\mathrm{FP}=$ Filter Paper, $\mathrm{S}=\mathrm{Soil}, \mathrm{T}=\mathrm{Treatment})$ 
The maximum germination was noted for the T. aestivum, $C$. album and $R$. dentatus. The highest supression of radicle was measured for E. helioscopia, A. fatua and C. album. T. aestivum was observed to produce the lowest radicle size. The maximum length of the seedling was recorded for E. helioscopia, T. aestivum, $R$. dentatus, and A. fatua. The lowest seedling length was found for P. minor. C. papa$y a$ benzyl isothiocyanate and associated compounds (e.g., phenethyl isothiocyanate, allyl isothiocyanate) are recognized as germination inhibitors (Wolf, 1984). Inhibitory actions may be due to reduced cell sizes and cell division (Ortega et al., 1988; Einhellig and Leather, 1988).

\section{Phytotoxic activity of $P$. roxburghii}

Results showed a significant reduction in the germination of T. aestivum, A. fatua and C. album - 54\%, $43 \%$ and $48 \%$, respectively - although no noteworthy impact on the growth of E. helioscopia, $R$. dentatus and $P$. minor has been recorded. The highest germination (98 per cent), was observed for E. helioscopia, P. minor and $R$. dentatus. C. album (41 percent) and $R$. dentatus (40 percent) showed radicle supression in $P$. roxburghii extract, while there was no significant result on the radicle size of A. fatua, T. aestivum, E. helioscopia and P. minor. P. roxburghii extract on soil induced a substantial reduction in the size of $R$. dentatus (51 per cent) and C. album (49 per cent). For A. fatua, T. aestivum, P. minor and E. helioscopia the maximum radicle size ( 98 per cent) was recorded. The data established that a minimum radicle size was observed for $C$. album (61 per cent) and $R$. dentatus (51 per cent). P. roxburghii extract delayed the seedling growth of A. fatua $(39 \%)$ followed by $R$. dentatus $(35 \%)$. In the same way, the seedling growth of $R$. dentatus (50 percent) and A. fatua (46 percent) was repressed in the extract applied to soil. For C. album, T. aestivum, P. minor and E. helioscopia the maximum seedling length (98 percent) was noted. For $A$. fatua (63 per cent) and $R$. dentatus (62 per cent) on filter paper and soil, correspondingly, the minimum seedling length was noted (see: Fig. 4).

For T. aestivum, limited germination has been noted. For E. helioscopia, C. album, T. aestivum and $P$. minor the maximum seedling length has been re- corded. The data determined that least seedling size was observed on filter paper and soil, for A. fatua and $R$. dentatus. Kato-Noguchi et al. (2009) stated that various Pinus sp. extracts exhibit herbicidal capacity. Melkania (1984) established possible inhibitory properties of the $P$. roxburghii extract. Hamrouni et al. (2015) studied the allelopathy of $P$. halepensis, indicating herbicidal activity. Amri et al. (2013) distinguished herbicidal capability of $P$. halepensis against cereal crop weeds. Monnier et al. (2011) recommended the Pinus needles' inhibitory effect. Fernandez et al. (2013) reported on the phytotoxic activity of $P$. halepensis, which could be autotoxic (Navarro-Cano et al., 2009).

Pesticide-based water contamination is also caused by improper storage and distribution of agrochemicals. The effects of pesticides on water quality are correlated with the following factors: the active ingredient in the formulation of pesticides, the pollutants present as impurities in the active ingredient, the additives combined with the active ingredient (wetting agents, diluents or solvents, stretchers, adhesives, buffers, preservatives and emulsifiers), the degradants produced during the chemical phase, and microbial agents. Two major human health impacts result from ingestion of pesticide-contaminated fish and shellfish, and the direct ingestion of water polluted with pesticides (Ongley et al., 1996). Over the past 20 to 30 years, the accelerated use of agrochemicals has increased productivity profitably, but it has also had an adverse effect on the quality of groundwater in many of the world's major agricultural areas. There has been serious concern about the contamination of groundwater, linked to nitrogen fertilizers and pesticides, from widespread, regular soil application as well as point sources (Hallberg, 1987). In order to ensure a decreased impact on water quality, environmentally sustainable policies should be implemented. Among these, rational fertilizer placement rates, timing, form and technology can lead to economic and environmental benefits; minimum cultivation systems can minimize soil erosion and avoid dispersed pollution losses; Conservation Agriculture can reduce surface runoff among sustainable cropping systems and can help conserve water (Stagnari et al. 2016). 


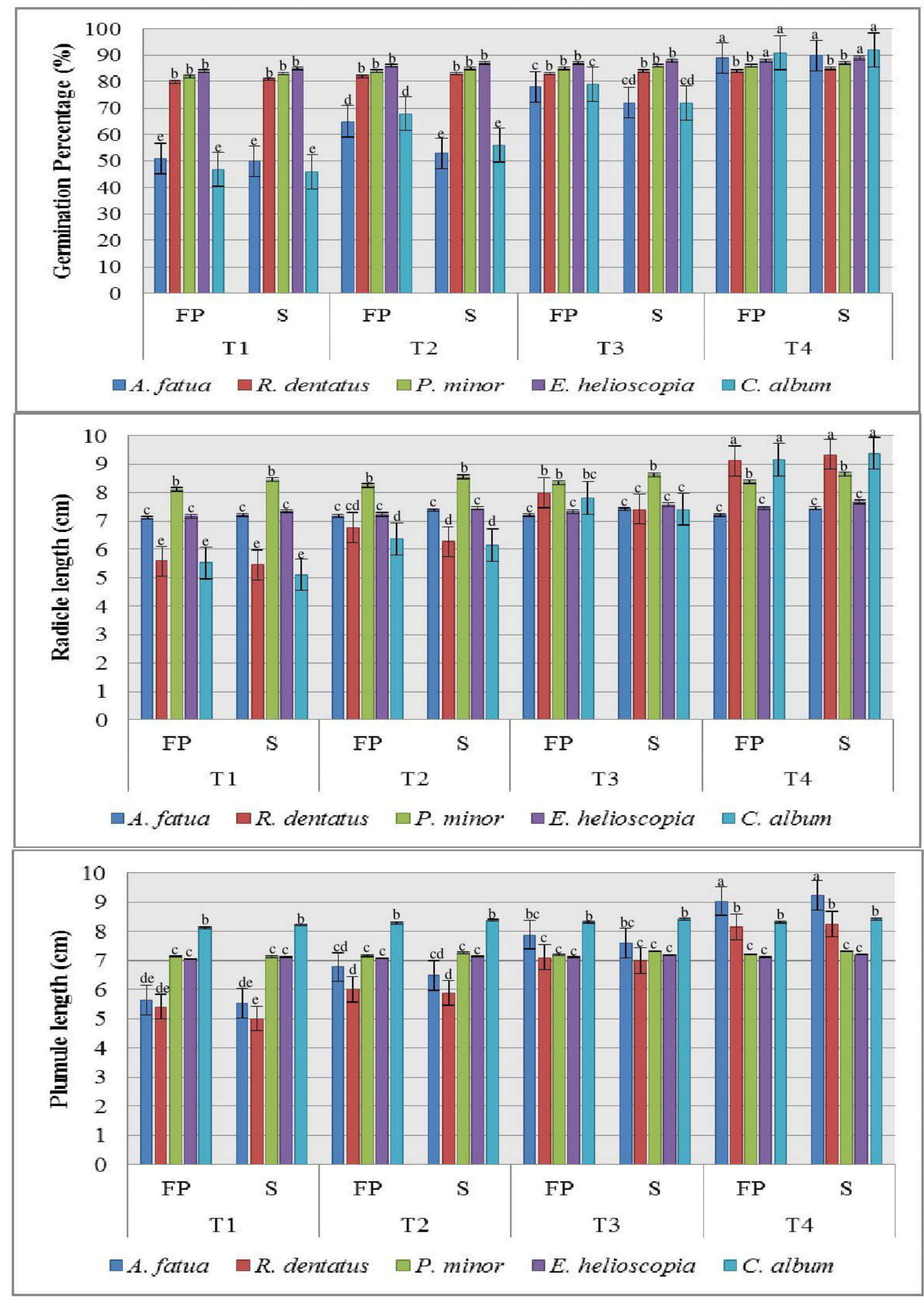

Fig. 4. Phytotoxic activity of $P$. roxburghii hexane extract against selected weeds (FP=Filter Paper, $\mathrm{S}=$ Soil, $\mathrm{T}=$ Treatment $)$ 


\section{CONCLUSION}

Current experiments suggest that the tested plant $n$-hexane extracts at greater concentrations decreases the seed germination and seedling length of the weeds. The data provided evidence of herbicidal potential of species viz. C. Papaya, L. camara, P. roxburghii and $R$. stricta against weeds (Rumex dentatus, Chenopodium album, Avena fatua and Phalaris minor) in dose-dependent manner, with a maximum decrease in germination and seedling elongation at $100 \%$ concentration of the extracts. The inhibitory effects on the germination and growth were established in the following order: R. stricta $>$ L. camara $>C$. papaya $>$ P. roxburghii. Based on these facts, field experiments are reccomended.

\section{REFERENCES}

Alam, SM. (1990). Effect of wheat straw extract on germination and seedling growth of wheat (cv. Pavon). Wheat Information Service, 71, 16-18.

Amri, I., Hamrouni, L., Hanana, M., Gargouri., S., Fezzani T., Jamoussi B. (2013). Chemical composition, physico-chemical properties, antifungal and herbicidal activities of Pinus halepensis Miller essential oils. Biology Agriculture and Horticulture, 29, 91-106.

Anwar, T., Khalid, S., Saeed, M., Mazhar, R., Qureshi, H., Rashid M. (2016). Allelopathic interference of leaf powder and aqueous extracts of hostile weed: Parthenium hysterophorus (Asteraceae). Science International 4, 86-93.

Anwar, T., Khalid, S., Mazhar, R., Qureshi, H. Rashid, M (2017). Herbicidal potential of selected species to overcome weed infestation in Triticum aestivum, Zea mays and Helianthus annuus. Pakistan Journal of Weed Science and Research, 23, 49-63.

Aryakia, E., Naghavi, MR., Farahmand, Z. Fazeli, SAHS (2015). Evaluating allelopathic effects of some plant species in tissue culture media as an accurate method for selection of tolerant plant and screening of bioherbicides. Journal of Agricultural Science and Technology, 17, 1011-1023.

Bora, IP., Singh, J., Borthakur R., Bora E. (1999). Allelopathic effect of leaf extracts of Acacia auriculiformis on seed germination of some agricultural crops. Annals of Forestry, 7, 143-146.

Einhellig FA, Leather GR. (1988). Potentials for exploiting allelopathy to enhance crop production. Journal of Chemical Ecology, 14, 1829-1844.
Fernandez, C., Santonja, M., Gros, R., Monnier, RY., Chomel, M., Baldy V., Melou AB. (2013). Allelochemicals of Pinus halepensis as drivers of biodiversity in Mediterranean open mosaic habitats during the colonization stage of secondary succession. Journal of Chemical Ecology, 39, 298-311.

Hallberg, GR. (1987). The impacts of agricultural chemicals on ground water quality. GeoJournal, 15, 283-295.

Hamrouni, L., Hanana, M., Amri, I., Romane, AE., Gargouri, S., Jamoussi, B. (2015). Allelopathic effects of essential oils of Pinus halepensis Miller: chemical composition and study of their antifungal and herbicidal activities. Archives of Phytopathological Plant Protection, 48, 145-158.

Hussain, MI., Gonzalez, L., Reigosa, MJ. (2011). Allelopathic potential of Acacia melanoxylon on the germination and root growth of native species. Weed Biology and Management, 11, 18-28.

Kamran, M., Raza, A., Ali, Q., Ali, HH., Chattha, MS. (2017). Investigating the influence of fertilizer and allelopathic water extracts on maize and associated weeds. Pakistan Journal of Weed Science and Research, 23, 361-378.

Kato-Noguchi, H., Fushimi, HY., Shigemori, H. (2009). An allelopathic substance in red pine needles (Pinus densiflora). Journal of Plant Physiology, 166, 442-446.

Khan, I., Ali, Z., Khan, MI., Hussain, Z., Khan, IA., Waqas, M., Khan, R. Khan, S. (2014). Allelopathic effects of some weeds on chickpea crop. Pakistan Journal of Weed Science and Research, 20, 207-211.

Kong, CH., Li, HB., Hu, F., Xu, XH., Wang, P. (2006). Allelochemicals released by rice roots and residues in soil. Plant Soil, 288, 47-56.

Maharjan, S., Shrestha BB, Jha PK (2007). Allelopathic effects of aqueous extract of Parthenium hysterophorus L. on seed germination and seedling growth of some cultivated and wild herbaceous species. Science World 5: 35-39

Melkania, NP. (1984). Influence of leaf leachates of certain woody species on agricultural crops. Indian Journal of Ecology, 11, 82-86.

Monnier, Y., Vila, B., Montes, N., Melou, AB., Prevosto, B., Fernandez, C. (2011). Fertilization and allelopathy modify Pinus halepensis saplings crown acclimation to shade. Trees, 25, 497-507.

Navarro-Cano, JA., Barbera, GG., Ruiz-Navarro, A., Castillo, VM. (2009). Pine plantation bands limit seedling recruitment of a perennial grass under semiarid conditions. Journal of Arid Environment, 73, 120-126.

Nekonam, MS., Kraimmojeni, H., Sharifnabi, B., Razmjoo, J., Amini, H., Bahrami, F. (2014). Assessment of some 
Anwar, T. Qureshi, H. (2021). Phytotoxic Activity of Bioactive Compounds from Four Plants against Selected Weeds in Agriculture. Acta Sci. Pol., Formatio Circumiectus, 20 (1), 33-42. DOI:

medicinal plants for their allelopathic potential against redroot pigweed (Amaranthus retroflexus). Journal of Plant Protection and Research, 54, 90-95.

Ongley ED. (1996). Control of water pollution from agriculture. FAO irrigation and draining paper. GEMS/Water collaborating centre, Canada centre for inland waters, Burlington, Canada.

Ortega, RC., Anaya, AL., Ramos, L. (1988). Effects of allelopathic compounds of corn pollen on respiration and cell division of watermelon. Journal of Chemical Ecology, 14, 71-86.

Padhy, B., Patnaik, PK., Tripathy, AK. (2000). Allelopathic potential of Eucalyptus leaf litter leachate on germination and seedling growth of finger millet. Allelopathy Journal, 7, 69-78.

Ramsumair, A., Mlambo, V.,Lallo, CHO. (2014). Effect of drying method on the chemical composition of leaves from four tropical tree species. Tropical Agriculture (Trinidad), 91, 179-186.

Stagnari, F., Jan, S., Angelica, G., Michele, P.. (2016). Sustainable agricultural practices for water quality protection. In: Water Stress and Crop Plants.

Tadele, D. (2014). Allelopathic Effects of Lantana (Lantana camara L.) leaf extracts on germination and early growth of three agricultural crops in Ethiopia. Momona Ethiopian Journal of Science, 6, 111-119.

Wolf, RB., Spencer, GF., Kwolek, WF. (1984). Inhibition of velvetleaf (Abutilon theophrasti) germination and growth by Benzyl Isothiocyanate, a natural toxicant. Weed Science, 32, 612-615.

Zackrisson, O., Nilsson, MC. (1992). Allelopathic effects by Empetrum hermaphroditum on seed germination of two boreal tree species. Canadian Journal of Forest Research, 22, 1310-1319.

\section{FITOTOKSYCZNE DZIAŁANIE ZWIAZZKÓW BIOAKTYWNYCH Z CZTERECH ROŚLIN NA WYBRANE CHWASTY W ROLNICTWIE}

\section{ABSTRAKT}

\section{Cel badań}

Stosowanie dużych dawek syntetycznych chemikaliów do zwalczania chwastów spowodowało uodpornienie tych ostatnich na herbicydy. Naturalne związki wytwarzane przez organizmy żywe stwarzają szerokie pole do poszukiwania ekologicznie bezpiecznych herbicydów. Przedstawione tu badania miały na celu zbadanie potencjału allelopatycznego ekstraktów heksanowych wybranych roślin w stosunku do chwastów pospolitych występujących w rolnictwie.

\section{Materiały i metody}

Allelopatyczny potencjał ekstraktów z roślin Carica papaya, Rhazya stricta, Lantana camara i Pinus roxburghii hexane przeciwko następującym chwastom. Euphorbia helioscopia, Rumex dentatus, Phalaris minor, Avena fatua i Chenopodium album oznaczono w stężeniu 100\%, 75\% i 50\% na podłożu glebowym, bibule filtracyjnej i agarze. Przyjętymi parametrami oceny potencjału allelopatycznego były kiełkowanie $(\%)$ oraz długość sadzonki $(\mathrm{cm})$. Analizę danych przeprowadzono za pomocą oprogramowania Statistica 9.

\section{Wyniki i wnioski}

Na podstawie uzyskanych wyników stwierdzono, że ekstrakt heksanowy z R. stricta, C. papaya, L. camara i $P$. roxburghii wykazuje możliwe działanie supresyjne, a spośród tej grupy eksytrakt L. camara wykazywał najbardziej wyraźny wpływ hamujący na wybrane chwasty. Skuteczność hamowania kiełkowania i wzrostu ustalono w następującej kolejności $R$. stricta $>$ L. camara $>$ C. papaya $>$ P. roxburghii. Zalecane są dalsze badania terenowe w celu oceny zdolności fitotoksycznej tych gatunków i ich przydatności jako herbicydów.

Słowa kluczowe: bioherbicydy, supresja wzrostu, fitotoksyczność 